\title{
PERBANDINGAN GAP DAN RTS SEBAGAI PREDIKTOR PERBURUKAN PASIEN CEDERA KEPALA
}

\author{
Tengku Isni Yuli Lestari Putri ${ }^{1)}$, Ahsan $^{2)}$, Sugiarto $^{3)}$, Winda Rofiyati ${ }^{4)}$, Heru Ginanjar Triyono ${ }^{5)}$, \\ Ratna Wirawati Rosyida', Muhammad G A Putra ${ }^{\text {7) }}$, Annisa Rahmania ${ }^{8)}$, Fitriyanti N Idrus ${ }^{9}{ }^{\text {( }}$ \\ 1,3,4,5,6,7 Fakultas Kesehatan, Universitas Alma Ata, Yogyakarta, Indonesia \\ ${ }_{2}$ Fakultas Kedokteran, Universitas Brawijaya, Malang, Indonesia \\ ${ }_{8}$ Fakultas Kesehatan, Institut Ilmu Kesehatan dan Teknologi Muhammdiyah Palembang, Indonesia \\ ${ }_{9}$ Program Studi D4 Keperawatan, Poltekes Kemenkes Ternate, Indonesia \\ email: tengkuisni15@almaata.ic.id
}

\begin{abstract}
Abstrak
Cedera kepala adalah cedera pada otak yang dapat menyebabkan perubahan fungsi serta struktur jaringan otak akibat mendapatkan dorongan mekanik eksternal seperti trauma tumpul maupun tusuk. Kejadian cedera kepala dan tingkat perburukan cedera kepala sangat tinggi di dunia. Oleh karena itu diperlukan penilaian awal untuk memprediksi perburukan pasien cedera kepala yaitu menggunakan GAP dan RTS. Tujuan penelitian untuk mengetahui perbandingan GAP dan RTS dalam memprediksi perburukan pasien cedera kepala. Desain penelitian observasional analitik dengan pendekatan retrospektif dengan purposive sampling. Responden berjumlah 245 rekam medis cedera kepala. Pengukuran dilakukan menggunakan lembar observasi. Analisis uji Receiver Operating Charateristic (ROC). Didapatkan hasil maisng-masing RTS dan GAP dalam memprediksi perburukan pasien cedera kepala mempunyai nilai $=0.851$ vs 0.806. RTS lebih baik dalam memprediksi perburukan pasien cedera kepala dibandingkan dengan GAP.
\end{abstract}

Kata kunci: cedera kepala, GAP, perburukan, RTS

\begin{abstract}
Head injury is an injury to the brain that can cause changes in the function and structure of brain tissue due to external mechanical impulses such as blunt or puncture trauma. The incidence of head injuries and the rate of deterioration of head injuries is very high in the world. Therefore an initial assessment is needed to predict the worsening of head injury patients using GAP and RTS. The purpose of this study was to determine the comparison of GAP and RTS in predicting worsening head injury in patients. Using analytic observational research design with a retrospective approach with purposive sampling. Total respondents are 245 head injury medical records. The measurements were taken by an observation sheet. The data was analyzed by using Receiver Operating Characteristics (ROC) tests. The results obtained that in predicting the worsening of head injury patients RTS has a value of 0.851 while GAP is 0.806. RTS is better than GAP in predicting worsening head injury patients.
\end{abstract}

Keywords: head Injury, GAP, worsening, RTS

\section{PENDAHULUAN}

Cedera kepala adalah cedera pada otak yang dapat menyebabkan perubahan fungsi serta struktur jaringan otak akibat mendapatkan dorongan mekanik eksternal seperti trauma tumpul maupun tusuk yang menyebabkan terjadinya gangguan fisik, intelektual, emosi, sosial, maupun vokasional baik sementara maupun permanen (Kowalak, Welsh, \& Mayer, 2017; Longo et al., 2012). Cedera kepala terdiri dari cedera kulit kepala, tengkorak (cranium dan tulang wajah) serta otak. Tingkat keparahan pada cedera kepala berhubungan dengan kerusakan otak serta patologi sekunder yang terkait (Walker, Colledge, Ralston, \& Penman, 2014).

Cedera kepala menjadi suatu masalah kesehatan masyarakat diseluruh dunia karena dapat meningkatkan angka kematian, kecacatan, serta mengurangi waktu produktif seseorang sehingga dapat meningkatkan beban sosial ekonomi yang besar (Frieden, Debra, \& Baldwin, 2016; Rubin, Peleg, Givon, \& Rozen, 2015).

Tingkat kejadian cedera kepala di seluruh dunia akan terus mengalami peningkatan terutama akibat adanya penggunaan kendaraan bermotor 
yang meningkat. Angka kejadian trauma di Amerika Serikat, menunjukkan grafik yang meningkat. Survei yang dilakukan antara 20012010 oleh Frieden, Debra \& Baldwin (2016) menemukan peningkatan jumlah cedera kepala mencapai 2.5 juta jiwa yang masuk instalasi gawat darurat dengan $87 \% \quad(2,213,826)$ telah mendapatkan pengobatan dan keluar dari ruangan emergensi, $11 \%(283,630)$ di rawat di rumah sakit dan 2\% (52.844) orang yang mengalami kematian di Amerika Serikat (Frieden et al., 2016). Di Eropa kejadian cedera kepala cukup tinggi mencapai 262 per 100.000 orang (Peeters et al., 2015).

Kejadian cedera kepala di Indonesia tergolong cukup tinggi sebagai salah satu penyebab kematian. Tingginya kejadian cedera kepala di Indonesia didapat dilihat dari angka kecelakaan lalu lintas serta jumlah pasien cedera kepala yang ada dirumah sakit. Kejadian kecelakaan lalu lintas di Indonesia pada tahun 2015 mencapai 98,9 ribu kasus. Angka ini meningkat daripada tahun sebelumnya mencapai 3,19\% dari 95,5 ribu kasus. Peningkatan data ini diikuti dengan peningkatan jumlah korban dunia sebanyak 504 orang yang meninggal dari 2719 kecelakaan lalu lintas pada tahun 2016 (BPS, 2017). Penyebab cedera kepala di Indonesia disebabkan oleh kecelakaan lalu lintas sebesar $14,9 \%$ dari total cedera yang dialami oleh masyarakat Indonesia (Riskesdas, 2013).

Cedera kepala mempunyai tingkat perburukan dan kematian yang tinggi dimana semakin tinggi derajat cedera kepala maka tingkat perburukan dan kematian akan semakin tinggi. Oleh karena itu, diperlukan penilaian awal yang akurat untuk mengetahui prognosis cedera kepala sebagai informasi mengenai perjalanan penyakit serta outcome penyakit tersebut (Hemingway et al., 2013). Melalui penilaian awal yang akurat ini diharapkan dapat memprediksi outcome serta penatalaksanaan yang sesuai dengan kondisi pasien. Penatalaksanaan pada pasien baik dengan prognosis baik maupun dengan prognosis buruk akan menentukan keputusan yang menentukan tindakan medis segera. Informasi ini sangat dibutuhkan oleh keluarga pasien sebagai gambaran kondisi yang terjadi pada pasien apakah baik maupun buruk prognosisnya (Kondo et al., 2011). Penilaian awal dengan alat skoring (trauma skoring) merupakan solusi termudah dalam memberikan jawaban kepada keluarga pasien terkait kondisi pasien.

Sistem skoring trauma sudah banyak dikembangkan dan digunakan baik di Indonesia maupun di dunia. Adapun sistem skoring trauma yang sering digunakan dalam memprediksi outcome pasien trauma yaitu GAP (Glasgow Coma Scale, Age

\section{\& Systolic Blood Pressure) dan RTS (Revised Trauma Scoring). \\ Glasgow coma scale, umur dan tekanan darah} sistolik (GAP) skor merupakan suatu sistem trauma skoring fisiologis yang diperkenalkan oleh kondo et al pada tahun 2011 (Kondo et al., 2011). GAP ini merupakan trauma skoring dari hasil modifikasi skor MGAP (Mechanism, Glasgow Coma Scale, Age dan Systolic Blood Pressure) yang dikembangkan oleh Sartorius et al pada tahun 2010. Trauma skoring MGAP pada tahun tersebut dianggap sebagai salah satu sistem skoring yang paling baik serta terbaru dalam memprediksi outcome di rumah sakit (Sartorius et al., 2010). Namun, Kondo et al, (2011) berasumsi bahwa salah satu komponen dari trauma skoring MGAP yakni mekanisme injury masih diragukan penggunaanya karena memberikan nilai yang tinggi terhadap trauma tusuk (Kondo et al., 2011). Padahal, tidak semua kondisi trauma penetrasi lebih parah dibandingkan dengan trauma tumpul. Selain itu, skor berdasarkan penilaian mekanisme trauma tusuk hanya mempengaruhi kurang dari $10 \%$ dari semua pasien trauma (Sartorius et al., 2010; Shoko, Shiraishi, Kaji, \& Otomo, 2010).

RTS pertama kali dikembangkan oleh Champion HR et al (1989) yang banyak digunakan sebagai referensi untuk skoring trauma (Champion et al., 1989). Variabel RTS juga digunakan pada Trauma Related Injury Severity Score (TRISS) yang merupakan salah satu skoring trauma dengan sistem anatomis dan fisiologis (Bouzat et al., 2016). Komponen RTS terdiri dari nilai GCS, laju respirasi serta tekanan darah sistolik (Kim et al., 2017). Skoring trauma RTS ini mempunyai kelemahan dalam perhitungannya yang cukup rumit serta komponen laju pernapasan dari RTS tidak terlalu berdampak signifikansi karena dipengaruhi oleh faktor lain seperti usia pasien, mekanisme cedera serta ventilasi mekanik (Kondo et al., 2011). Namun, RTS masih sering digunakan serta cukup baik memprediksi outcome pasien yang mengalami trauma (Jung et al., 2016).

Penelitian yang dilakukan oleh Ahun et al (2014) menyatakan bahwa GAP lebih baik dalam memprediksi outcome pasien trauma dibandingkan dengan RTS dengan nilai AUC masing-masing 0.901 dan 0.727 (Ahun et al., 2014). Penelitian Jeong et al (2017) juga menyatakan bahwa GAP lebih baik dalam memprediksi outcome pasien trauma dibandingkan dengan RTS dengan nilai AUC masing-masing 0.912 dan 0.906 (Jeong et al., 2017). Berbeda dengan hasil penelitian yang dilakan oleh Kondo et al (2011) yang menyatakan bahwa RTS lebih baik dalam memprediksi outcome pasien 
trauma dibandingkan dengan GAP dengan nilai AUC masing-masing 0.966 dan 0.965 (Kondo et al., 2011).

Kedua trauma skoring dapat memprediksi kematian yang cukup tinggi pada cedera kepala. Namun, kedua kedua trauma skoring ini memiliki perbedaan penilaian dan salah satu komponen. Di RTS dan GAP terdapat komponen umur dan respirasi. Umur menjadi komponen penilaian GAP karena semakin tua umur responden, maka fisiologis tubuh akan menurun. Sedangkan untuk di RTS terdapat respirasi dimana respirasi yang di atas maupun di bawah normal dapat menjadi gambaran tubuh mengalami perburukan. Namun, penelitian yang dilakukan oleh Irawan et al menyatakan bahwa penggunaan RTS kurang akurat dalam memprediksi outcome pasien terutama disabilitas di bandingkan dengan GCS (Irawan, Setiawan, Dewi, \& Dewanto, 2010). Namun, Kondo et al menyatakan RTS akurat dalam memprediksi outcome pasien terutama perburukan dan kematian pasien (Kondo et al., 2011)

Hasil studi pendahuluan yang dilakukan peneliti di RSUD dr. Slamet Martodirdjo Pamekasan didapatkan bahwa pada tahun 2017, prevalensi cedera kepala mencapai 281 orang pasien, adapun jumlah pasien cedera kepala ringan berjumlah 241 orang pasien (86\%), cedera kepala sedang berjumlah 34 orang pasien $(12 \%)$ dan cedera kepala berat berjumlah $6(2 \%)$ orang pasien dengan pasien yang meninggal berjumlah 2 orang $(0.2 \%)$.

Data tahun 2018 dari bulan Januari-November 2018, prevalensi cedera kepala RSUD dr. Slamet Martodirdjo Pamekasan mencapai 352 orang pasien, adapun jumlah pasien cedera kepala ringan berjumlah 337 orang pasien (96\%), cedera kepala

sedang berjumlah $7(1.9 \%)$ orang pasien dan cedera kepala berat berjumlah $8(2 \%)$ orang pasien dengan pasien yang meninggal mencapai 8 orang $(2 \%)$. Hasil wawancara yang dilakukan pada petugas medis, didapatkan pasien cedera kepala rata-rata disebabkan oleh kecelakaan lalu lintas dan petugas medis menyatakan belum menggunakan trauma skoring di IGD RSUD dr. Slamet Martodirdjo Pamekasan.

Penelitian ini bertujuan meneliti tentang perbandingan GAP (Glasgow Coma Scale, Age, Systolic Blood Pressure) dan RTS (Revised Trauma Scoring) dalam memprediksi perburukan pasien cedera kepala di IGD RSUD dr. Slamet Martodirdjo Pamekasan.

\section{METODE PENELITIAN}

Penelitian ini menggunakan desain observasional analitik dengan pendekatan retrospektif. Responden penelitian berjumlah 245 data rekam medis pasien cedera kepala dengan metode purposive sampling di RSUD dr. Slamet Martodirdjo Pamekasan pada tanggal 19 Februari - 5 Maret 2019. Instrumen penelitian berupa lembar observasi. Perbedaan nilai AUC GAP dan RTS menggunakan metode komparatif ROC dalam menentukan AUC, cut-off point, sensitivitas dan spesifisitas pada GAP dan RTS. Penelitian ini dilakukan setelah mendapatkan persetujuan etik (Ethical Clearance) dari pihak RSUD dr. Slamet Martodirdjo Pamekasan dengan No.070/218/432.603/2019.

\section{HASIL DAN PEMBAHASAN}

Tabel 1. Karateristik Responden Berdasarkan Skor GAP, RTS, Umur, Tekanan Darah Sistolik, GCS dan Respirasi

\begin{tabular}{lccccc}
\hline \multicolumn{1}{c}{ Variabel } & N & Mean & Median & Min-Max & SD \\
\hline Skor GAP & 245 & 18.58 & 19 & $14-24$ & 2.492 \\
Skor RTS & 245 & 10.36 & 11 & $7-12$ & 2.904 \\
Umur & 245 & 49.29 & 47 & $25-65$ & 12.73 \\
Tekanan darah sistolik & 245 & 97.68 & 95 & $68-134$ & 21.744 \\
GCS & 245 & 12.31 & 13 & $7-15$ & 2.636 \\
Respirasi & 245 & 22.04 & 20 & $7-36$ & 8.26 \\
\hline
\end{tabular}

Sumber: Data Primer (2019)

Berdasarkan Tabel 1 dapat diketahui skor GAP yang paling tinggi bernilai 24 dan paling rendah bernilai 14 dengan nilai rata-rata yaitu 18.58 . Skor RTS yang paling tinggi bernilai 12 dan paling rendah bernilai 7 dengan nilai rata-rata yaitu 10.36 . Responden yang paling tua berumur 65 tahun dan yang paling muda berumur 25 tahun dengan ratarata mencapai 49.29 tahun.

Tekanan darah sistolik pasien yang paling tinggi sebesar $134 \mathrm{mmHg}$ dan yang paling rendah sebesar $68 \mathrm{mmHg}$ dengan rata-rata mencapai 97.68 $\mathrm{mmHg}$. Skor GCS pasien yang paling tinggi adalah sebesar 15 dan paling rendah sebesar 7 dengan rata- 
rata mencapai 12.31 . Respirasi pasien yang paling tinggi sebesar 36x/menit dan paling rendah sebesar $7 \mathrm{x} /$ menit dengan rata-rata sebesar $22.04 \mathrm{x} /$ menit.

Tabel 2. Karateristik Responden Berdasarkan Perburukan, Kategori GAP, Kategori RTS, Jenis Kelamin, Cedera Kepala dan Mekanisme Cedera Kepala

\begin{tabular}{llcc}
\hline \multirow{2}{*}{ Variabel } & \multicolumn{1}{c}{ Kategori } & f & \% \\
\hline Perburukan & Tidak perburukan & 160 & 65.3 \\
& Perburukan & 85 & 34.7 \\
Kategori & Resiko tinggi $(<19)$ & 104 & 42.4 \\
GAP & Resiko rendah $(\geq 19)$ & 141 & 57.6 \\
Kategori & Resiko tinggi $(<9)$ & 46 & 18.8 \\
RTS & Resiko rendah $(\geq 9)$ & 199 & 81.2 \\
Jenis & Laki-laki & 190 & 77.6 \\
Kelamin & Perempuan & 55 & 22.4 \\
Cedera & Cedera kepala ringan & 138 & 56.3 \\
Kepala & Cedera kepala sedang & 81 & 33.1 \\
& Cedera kepala berat & 26 & 10.6 \\
Mekanisme & Jatuh & 73 & 29.8 \\
cedera & Kecelakaaan lalu lintas & 172 & 70.2 \\
\hline Sumber: Data & Primer $(2019)$ & & \\
\hline
\end{tabular}

Sumber: Data Primer (2019)

Tabel 2 menjelaskan responden paling dominan tidak mengalami perburukan dengan jumlah sebanyak 160 (65.3\%) responden. Kategori GAP yang paling dominan yaitu kategori resiko rendah $(\geq 19)$ dengan jumlah sebanyak 141 (57.6\%) responden. Kategori RTS yang paling dominan yaitu kategori resiko rendah $(\geq 9)$ dengan jumlah sebanyak $199(81.2 \%)$ responden. Jenis kelamin responden yang paling dominan yaitu laki-laki dengan jumlah sebanyak 190 (77.6\%) responden. Cedera kepala responden yang paling dominan berkategori sebagai cedera kepala ringan dengan jumlah 138 (56.3\%) responden. Mekanisme cedera kepala responden yang paling dominan disebabkan oleh kecelakaan lalu lintas dengan jumlah sebanyak $172(70.2 \%)$ responden.

\section{Analisa ROC}
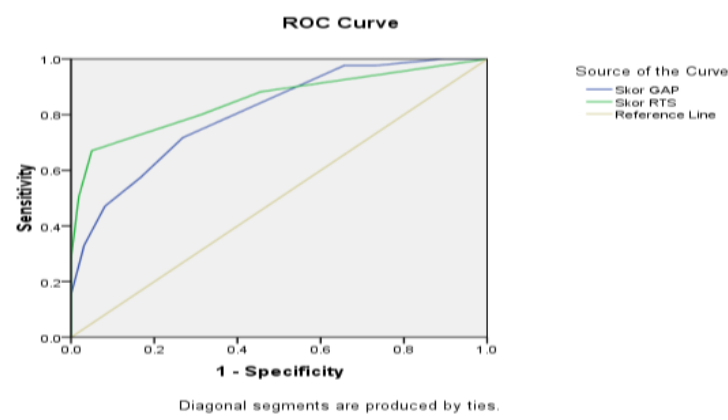
Skor OAP
- Stor RTS
Roterenco

Gambar 1. Kurva ROC GAP dan RTS
Gambar 1 menjelaskan kurva ROC GAP dan RTS sebagai prediktor perburukan cedera kepala. Berdasarkan kurva tersebut, didapatkan AUC RTS lebih tinggi dibandingkan dengan AUC GAP. Adapun kurva ROC GAP dan RTS dijelaskan pada tabel 3 .

Tabel 3. Deskripsi Nilai Area Under Curve (AUC) GAP dan RTS

\begin{tabular}{lccccc}
\hline & \multirow{2}{*}{ AUC } & $\begin{array}{c}\text { Std. } \\
\text { Error }\end{array}$ & $\begin{array}{c}\text { p- } \\
\text { value }\end{array}$ & \multicolumn{2}{c}{ IK 95 \% } \\
\cline { 5 - 6 } & & & LB & UB \\
\hline Skor & 0.806 & 0.028 & 0.000 & 0.751 & 0.862 \\
GAP & & & & & \\
Skor & 0.851 & 0.029 & 0.000 & 0.796 & 0.907 \\
RTS & & & & & \\
\hline
\end{tabular}

Sumber: Data Primer (2019)

Tabel 3 menunjukkan GAP memiliki nilai $\mathrm{p}=0.000$ dan AUC 0.806 yang menjelaskan GAP dapat menjadi prediktor kuat terkait perburukan pada pasien cedera kepala. RTS juga memiliki nilai $\mathrm{p}=0.000$ dan AUC 0.851 yang menjelaskan RTS dapat menjadi prediktor kuat terkait perburukan pada pasien cedera kepala.

Tabel 4. Cut off Point, Sensitivitas dan Spesifisitas GAP dan RTS

\begin{tabular}{lccc}
\hline & $\begin{array}{c}\text { Cut off } \\
\text { Point }\end{array}$ & Sensitivitas & Spesifisitas \\
\hline Skor & 18.5 & 0.72 & 0.73 \\
GAP & & & \\
Skor & 9.5 & 0.67 & 0.95 \\
RTS & & & \\
\hline
\end{tabular}

Sumber: Data Primer (2019)

Berdasarkan tabel 4 didapatkan nilai cut off point skor GAP berada pada skor 18.5 dengan nilai sensitivitas sebesar 0.72 dan spesifisitas sebesar 0.73 . Nilai sensitivitas sebesar 0.72 menunjukkan secara klinis kemampuan GAP untuk menghasilkan nilai positif atau adanya perburukan cedera kepala sebesar $72 \%$. Nilai spesifisitas sebesar 0.73 menunjukkan secara klinis kemampuan GAP untuk menghasilkan nilai negatif atau tidak perburukan cedera kepala sebesar $73 \%$. Tabel 5 juga didapatkan nilai cut off point skor RTS berada pada skor 9.5 dengan nilai sensitivitas sebesar 0.67 dan spesifisitas sebesar 0.95. Nilai sensitivitas sebesar 0.67 menunjukkan secara klinis kemampuan RTS untuk menghasilkan nilai positif atau adanya perburukan cedera kepala sebesar $67 \%$. Nilai spesifisitas sebesar 0.95 menunjukkan secara klinis kemampuan RTS untuk menghasilkan 
nilai negatif atau tidak perburukan cedera kepala sebesar $95 \%$.

Hasil penelitian ini menunjukkan bahwa RTS merupakan prediktor yang lebih baik dibandingkan dengan GAP dalam memprediksi perburukan pada pasien cedera kepala di IGD RSUD dr. Slamet Martodirdjo Pamekasan dengan nilai AUC $\mathrm{GAP}=0.806$ dan AUC RTS=0.851. Hasil penelitian ini menunjukkan nilai cutt off point RTS berada pada nilai 9.5 dengan nilai sensitivitas 0.67 yang menjelaskan nilai positif atau adanya perburukan cedera kepala sebesar $67 \%$ dan spesifisitas sebesar 0.95 menunjukkan secara klinis kemampuan RTS untuk menghasilkan nilai negatif atau tidak perburukan cedera kepala sebesar 95\%. Untuk GAP, nilai cutt off point berada pada nilai 18.5 dengan nilai sensitivitas 0.72 yang menjelaskan nilai positif atau adanya perburukan cedera kepala sebesar $72 \%$ dan spesifisitas 0.73 yang menjelaskan nilai negatif atau tidak adanya perburukan cedera kepala sebesar $73 \%$.

Cutt off point atau titik potong pada RTS dibagi menjadi 2 kategori yaitu nilai RTS <9 (resiko tinggi) dan $\geq 9$ (resiko rendah). RTS yang mempunyai nilai $<9$ rata-rata mengalami perburukan dibandingkan dengan dengan RTS yang memiliki nilai $\geq 9$. Untuk GAP, titik potongnya dibagi menjadi 2 kategori yaitu <19 (resiko tinggi) dan $\geq 19$ (resiko rendah). GAP yang mempunyai nilai <19 rata-rata mengalami perburukan dibandingkan dengan GAP yang memiliki nilai $\geq 19$.

Hasil penelitian ini sejalan dengan penelitian Hung et al tahun 2017 dan Kondo et al tahun 2011 yang menyatakan bahwa RTS merupakan trauma skoring yang dapat memprediksi outcome pasien dengan trauma seperti cedera kepala dibandingkan dengan trauma skoring yang lain seperti GAP (Hung et al., 2017; Kondo et al., 2011).

RTS dan GAP memiliki perbedaan pada cara penilaian dan komponen. Pada RTS, GCS awal masuk IGD dikategorikan menjadi 4 penilaian yaitu GCS 13-15 mempunyai nilai 4, GCS 9-12 mempunyai nilai 3, GCS 6-8 mempunyai nilai 2 dan GCS 3 mempunyai nilai 0 . Sedangkan pada GAP, penilaian GCS langsung berdasarkan hasil observasi GCS saat pertama kali masuk IGD (Irawan et al., 2010; Kondo et al., 2011).

Tekanan darah sistolik pada RTS dan GAP juga memiliki perbedaan penilaian dimana RTS membuat 5 kategori penilaian. tekanan darah yang $>89 \mathrm{mmHg}$ mempunyai nilai $4,76-89 \mathrm{mmHg}$ mempunyai nilai $3,50-75 \mathrm{mmHg}$ mempunyai nilai 2 , 1-49 mmHg mempunyai nilai 1 dan $0 \mathrm{mmHg}$ mempunyai nilai 0 . Adapun total penilannya mencapai nilai 12. Sedangkan tekanan darah sistolik pada GAP mempunyai 3 kategori penilaian yaitu $>120 \mathrm{mmHg}$ mempunyai nilai 6, 60-120 mmHg mempunyai nilai 4 dan $<60 \mathrm{mmHg}$ mempunyai nilai 0 (Irawan et al., 2010; Kondo et al., 2011).

RTS dan GAP juga mempunyai perbedaan komponen yaitu respirasi rate pada RTS dan usia pada GAP. Respirasi rate/frekuensi pernapasan memiliki hubungan terkait dengan perburukan pasien cedera kepala. Yu et al tahun 2010 menjelaskan bahwa pasien dengan frekuensi pernapsan yang <12 $\mathrm{x} /$ menit meningkatkan perburukan maupun resiko kematian pasien cedera kepala (Yu et al., 2012). Perubahan frekuensi pernapasan dari rentang normal mengakibatkan penurunan saturasi oksigen di darah dan perfusi jaringan menurun. Perfusi oksigen yang rendah pada otak dapat menyebabkan perburukan pada pasien cedera kepala. Hal ini dijelaskan pada penelitian Safrizal et al tahun 2013 yang menjelaskan bahwa terdapat hubungan antara perfusi oksigen ke otak dengan perburukan pasien yang mana menjelaskan bahwa perfusi oksigen ke otak yang rendah akan menyebabkan perburukan pada pasien cedera kepala (Safrizal, 2013).

Sedangkan pada GAP terdapat komponen usia yang berpengaruh terhadap perburukan. Penelitian yang dilakukan oleh Lingsma et al tahun 2014 menyatakan mayoritas pasien dengan cedera kepala dapat pulih seutuhnya dalam kurun waktu 3-6 bulan meskipun ada beberapa yang mengalami defisit neurologis. Berdasarkan dari jumlah 485 pasien, ratarata berumur 44 tahun hingga umur lansia atau lebih dari 65 tahun memiliki outcome yang buruk paska cedera kepala (Lingsma et al., 2015).

Pasien yang berumur lebih dari 55 tahun mempunyai resiko komplikasi penyakit defisit neurologis yang lebih besar. Defisit neurologis dapat mengindikasikan tentang outcome yang buruk pada pasien dengan cedera kepala. Salah satu penyakit yang dapat dialami oleh pasien tersebut yaitu demensia. Defisit neurologis lain yang bersifat kronik dapat menyebabkan penyakit alzheimer, parkinson maupun amytrophiclateral sclerosis. Penyakitpenyakit ini dapat terjadi pada pasien dengan usia lebih dari 55 tahun (Faden \& Loane, 2015; Gardner et al., 2014).

Proses penyembuhan pada cidera kepala dapat dinilai dari tidak adanya disabilitas pasien. Usia di atas 65 tahun atau lanjut usia menunjukkan penurunan fungsi neurologis serta lebih besar mengalami disabilitas dibandingkan dengan usai dibawah 65 tahun. Hal ini merupakan suatu proses degeneratf yang di alami pada usia lanjut sehingga mempengaruhi penyembuhan dan perbaikan secara fisiologis dengan kasus cedera kepala (Sherwood, 2016). 
Berdasarkan penjelasan tersebut, dapat disimpulkan bahwa RTS merupakan trauma skoring yang paling baik memprediksi perburukan pasien cedera kepala dibandingkan dengan GAP dan terdapat perbedaan komponen pada kedua trauma skoring tersebut.

\section{KESIMPULAN DAN SARAN}

RTS dapat memprediksi perburukan pasien cedera kepala lebih baik dibandingkan dengan GAP. RTS dapat digunakan oleh rumah sakit untuk melakukan skrining pasien yang beresiko mengalami perburukan. Untuk penelitian selanjutnya, dapat menggunakan sampel dalam jumlah yang lebih banyak dan metode yang berbeda.

Perlunya penerapan sistem skoring RTS dalam memprediksi perburukan pasien cedera kepala dalam rangka menurunkan angka mortalitas pasien dan meningkatkan kualitas pelayanan di rumah sakit. Perlunya penerapan sistem skoring RTS oleh perawat dalam menangani pasien cedera kepala sebagai pedoman dalam penatalaksanaan cedera kepala. Peneliti selanjutnya dapat melakukan penelitian dengan prospektif sehingga dapat melakukan penilaian langsung.

\section{REFERENSI}

Ahun, E., Koksal, O., Sigirli, D., Torun, G., Donmez, S. S., \& Armagan, E. (2014). Value of the Glasgow coma scale, age, and arterial blood pressure score for predicting the mortality of major trauma patients presenting to the emergency department. Ulus Travma Acil Cerrahi Derg, 20(4), 241-247. doi:10.5505/tjtes.2014.76399

Awaloei, A. C., Mallo, N. T. S., \& Tomuka, D. (2016). Gambaran cedera kepala yang menyebabkan kematian di Bagian Forensik dan Medikolegal RSUP Prof Dr. R. D. Kandou periode Juni 2015 - Juli 2016. Jurnal e-Clinic, 4(2), 1-5.

Bouzat, P., Legrand, R., Gillois, P., Ageron, F.-X., Brun, J., Savary, D., . . Payen, J.-F. (2016). Prediction of intra-hospital mortality after severe trauma: which pre-hospital score is the most accurate? Injury, 47(1), 14-18. doi:https://doi.org/10.1016/j.injury.2015.10.035

BPS. (2017). Berapa Jumlah Kecelakaan Lalu Lintas di Indonesia.

Champion, H. R., Sacco, W. J., Copes, W. S., Gann, D. S., Gennarelli, T. A., \& Flanagan, M. E. (1989). A Revision of the Trauma Score. The Journal of Trauma, 29(5), 623-629.
Faden, A. I., \& Loane, D. J. (2015). Chronic neurodegeneration after traumatic brain injury: Alzheimer disease, chronic traumatic encephalopathy, or persistent neuroinflammation? Neurotherapeutics, 12(1), 143-150. doi:10.1007/s13311-014-0319-5

Frieden, T. R., Debra, H., \& Baldwin, G. (2016). Traumatic Brain Injury In the United States: Epidemiology and Rehabilitation. Retrieved from USA:

Gardner, R. C., Burke, J. F., Nettiksimmons, J., Kaup, A., Barnes, D. E., \& Yaffe, K. (2014). Dementia risk after traumatic brain injury vs nonbrain trauma: the role of age and severity. JAMA Neurol, 71(12), 1490-1497. doi:10.1001/jamaneurol.2014.2668

Hemingway, H., Croft, P., Perel, P., Hayden, J. A., Abrams, K., Timmis, A., . . Group, P. (2013). Prognosis research strategy (PROGRESS) 1: a framework for researching clinical outcomes. BMJ, 346, e5595. doi:10.1136/bmj.e5595

Humphreys, I., Wood, R. L., Phillips, C. J., \& Macey, S. (2013). The costs of traumatic brain injury: a literature review. Clinicoecon Outcomes Res, 5 , 281-287. doi:10.2147/CEOR.S44625

Hung, Y. W., He, H., Mehmood, A., Botchey, I., Saidi, H., Hyder, A. A., \& Bachani, A. M. (2017). Exploring injury severity measures and in-hospital mortality: A multi-hospital study in Kenya. Injury, 48(10), 2112-2118. doi:https://doi.org/10.1016/j.injury.2017.07.001

Irawan, H., Setiawan, F., Dewi, \& Dewanto, G. (2010). Comparison of Glasgow Coma Scale and Revised Trauma Score to Predict Disability of Head Trauma Patient in Atma Jaya Hospital (Vol. 60).

Jeong, J. H., Park, Y. J., Kim, D. H., Kim, T. Y., Kang, C., Lee, S. H., . . . Lim, D. (2017). The new trauma score (NTS): a modification of the revised trauma score for better trauma mortality prediction. BMC Surg, 17(1), 77. doi:10.1186/s12893-017-0272-4

Jung, K., Lee, J. C.-J., Park, R. W., Yoon, D., Jung, S., Kim, Y., Kwon, J. (2016). The Best Prediction Model for Trauma Outcomes of the Current Korean Population: a Comparative Study of Three Injury Severity Scoring Systems. Korean J Crit Care Med, 31(3), 221-228. doi:10.4266/kjccm.2016.00486 
Kim, S. C., Kim, D. H., Kim, T. Y., Kang, C., Lee, S. H., Jeong, J. H., . . . Lim, D. (2017). The Revised Trauma Score plus serum albumin level improves the prediction of mortality in trauma patients. The American Journal of Emergency Medicine, 35(12), 1882-1886. doi:https://doi.org/10.1016/j.ajem.2017.06.0 27

Kondo, Y., Abe, T., Kohshi, K., Tokuda, Y., Cook, E. F., \& Kukita, I. (2011). Revised trauma scoring system to predict in-hospital mortality in the emergency department: Glasgow Coma Scale, Age, and Systolic Blood Pressure score. Crit Care, 15(4), R191. doi:10.1186/cc10348

Kowalak, P. J., Welsh, W., \& Mayer, B. (2017). Buku Ajar Patofisiologi. Jakarta: EGC.

Lingsma, H. F., Yue, J. K., Maas, A. I., Steyerberg, E. W., Manley, G. T., \& Investigators, T.-T. (2015). Outcome prediction after mild and complicated mild traumatic brain injury: external validation of existing models and identification of new predictors using the TRACK-TBI pilot study. J Neurotrauma, 32(2), 83-94. doi:10.1089/neu.2014.3384

Longo, Fauci, Kasper, Hauser, Jameson, \& Loscalzo. (2012). Harrison's princple of internal medicine 18th edition. USA: McGraw-Hill Companies.

Peeters, W., van den Brande, R., Polinder, S., Brazinova, A., Steyerberg, E. W., Lingsma, H. F., \& Maas, A. I. (2015). Epidemiology of traumatic brain injury in Europe. Acta Neurochir (Wien), 157(10), 1683-1696. doi:10.1007/s00701-015-2512-7

Putra, D. S. E., Indra, M. R., Sargowo, D., \& fathoni, M. (2016). Nilai Skor Glasgow Coma Scale, Age, Systolic Blood Pressure (Gap Score) Dan Saturasi Oksigen Sebagai Prediktor Mortalitas Pasien Cidera Kepala Di Rumah Sakit Saiful Anwar Malang. Jurnal Hesti Wira Sakti,, 4(2), 13-28.

Riskesdas. (2013). Riset Kesehatan Dasar 2013.
Ristanto, R., Indra, M. R., Poeranto, S., \& Rini, I. S. (2017). Akurasi Revised Trauma Score Sebagai Prediktor Mortality Pasien Cedera Kepala. 2017, 4(2), 15. Retrieved from https://jurnal.poltekkessoepraoen.ac.id/ index.php/HWS/article/view/144

Rubin, G., Peleg, K., Givon, A., \& Rozen, N. (2015). Upper extremity fractures among hospitalized road traffic accident adults. The American Journal of Emergency Medicine, 33(2), 250253.doi:https://doi.org/10.1016/j.ajem.2014.11.048

Safrizal. (2013). Hubungan Nilai Oxygen Deliverydengan OutcomeRawatan Pasien Cedera Kepala Sedang. Andalas, Fakultas Kedokteran.

Sartorius, D., Le Manach, Y., David, J. S., Rancurel, E., Smail, N., Thicoipe, M., . . Riou, B. (2010). Mechanism, glasgow coma scale, age, and arterial pressure (MGAP): a new simple prehospital triage score to predict mortality in trauma patients. Crit Care Med, 38(3), 831-837. doi:10.1097/CCM.0b013e3181cc4a67

Sherwood, L. (2016). Fisiologi Manusia Dari Sistem ke Sistem Edisi 8. Jakarta: EGC.

Shoko, T., Shiraishi, A., Kaji, M., \& Otomo, Y. (2010). Effect of pre-existing medical conditions on inhospital mortality: analysis of 20,257 trauma patients in Japan. J Am Coll Surg, 211(3), 338346. doi:10.1016/j.jamcollsurg.2010.04.010

Walker, B. R., Colledge, N. R., Ralston, S. H., \& Penman, I. D. (2014). Davidson's Principle \& Practice of Medicine 22nd Edition. British: Elsevier.

Yu, A. H.-y., Cheng, C. H., Yeung, J. H. H., Poon, W. S., Ho, H. f., Chang, A., \& Rainer, T. H. (2012). Functional outcome after head injury: Comparison of 12\&\#x2013;45 year old male and female hormonally active patients. Injury, 43(5), 603-607. doi:10.1016/j.injury.2010.08.016

Zamzami, N. M., Fuadi, I., \& Nawawi, A. M. (2013). Angka Kejadian dan Outcome Cedera Otak di RS. Hasan Sadikin Bandung Tahun 2008-2010. Jurnal Neuroanestesia Indonesia, 2(2), 89-94. 